Article

\title{
Climate Adaptability Based on Indoor Physical Environment of Traditional Dwelling in North Dong Areas, China
}

\author{
Fupeng Zhang ${ }^{1,2}$, Lei Shi ${ }^{1,2}$, Simian Liu ${ }^{1,2, *}$, Jiaqi Shi ${ }^{1,2}$, Qian Ma ${ }^{1,2}$ and Jinyue Zhang ${ }^{1,2}$ \\ 1 School of Architecture and Art, Central South University, Changsha 410075, China; \\ 201301004@csu.edu.cn (F.Z.); shilei@csu.edu.cn (L.S.); 181301013@csu.edu.cn (J.S.); \\ 201311004@csu.edu.cn (Q.M.); $151301005 @$ csu.edu.cn (J.Z.) \\ 2 Health Building Research Center, Central South University, Changsha 410075, China \\ * Correspondence: 217034@csu.edu.cn
}

check for updates

Citation: Zhang, F.; Shi, L.; Liu, S.; Shi, J.; Ma, Q.; Zhang, J. Climate Adaptability Based on Indoor Physical Environment of Traditional Dwelling in North Dong Areas, China. Sustainability 2022, 14, 850. https://doi.org/10.3390/su14020850

Academic Editor: Baojie He

Received: 17 December 2021

Accepted: 11 January 2022

Published: 12 January 2022

Publisher's Note: MDPI stays neutral with regard to jurisdictional claims in published maps and institutional affiliations.

Copyright: (C) 2022 by the authors. Licensee MDPI, Basel, Switzerland. This article is an open access article distributed under the terms and conditions of the Creative Commons Attribution (CC BY) license (https:// creativecommons.org/licenses/by/ $4.0 /)$.

\begin{abstract}
In this study, climate-responsive solutions used in traditional dwellings in the North Dong region of China were identified, and the impact of these solutions on the indoor physical environment and energy consumption was analysed. First, over the course of a year, sample dwellings and shortterm on-site indoor physical environment measurements were selected from the local climate. Then, three building materials, namely, brick, wood, and rammed earth, and different structural forms were selected to simulate the indoor thermal environment, ventilation conditions, and energy consumption of traditional dwellings. The study also summarised the advantages and disadvantages of the physical environment of traditional dwellings in response to climate characteristics. The results showed that the fluctuation in indoor temperature and humidity of typical dwellings in the North Dong region is approximately $5{ }^{\circ} \mathrm{C}$, which is $14 \%$ lower than that outdoors. Traditional Dong dwellings have good indoor conditioning abilities. Traditional wood structure dwellings can save $26 \%$ and $39 \%$ of energy per year compared with those of raw earth and brick wood, respectively. Traditional dwellings in the Dong region are well adapted to the local climate in terms of form, materials, and structure and contribute to climate-responsive buildings in the harsh climatic conditions of the region. The solutions used in these dwellings can also be used to design new climate-responsive buildings; however, the indoor thermal comfort is not entirely satisfactory. We proposed an effective adaptation strategy for Dong traditional dwellings.
\end{abstract}

Keywords: North Dong areas; traditional dwelling; indoor physical environment; climate adaptability; monitoring and simulation

\section{Introduction}

Climate change and energy shortage are some of the most prominent problems that the world is facing today. The building sector accounts for approximately $30 \%$ of the world's total generated greenhouse gas emissions [1,2]. The whole life cycle carbon emissions of buildings in China increased by nearly four times from 2018 to 2020, accounting for $51.3 \%$ of the country's total carbon emissions [3,4]. The building sector accounts for $40 \%$ of global energy consumption; buildings in developed countries account for $35-40 \%$ of total energy consumption, $30-60 \%$ of which is used to regulate the indoor environment of buildings [5-7]. In China, the construction sector accounts for $46.5 \%$ of the country's total energy consumption [8]. The Chinese government, on the one hand, is committed to reaching peak carbon emissions by 2030 and becoming a carbon-neutral society by 2060 , and, on the other hand, is committed to limiting energy consumption in buildings to $<1 \%$ based on ensuring comfort and health $[9,10]$. Improving building energy efficiency by exploring passive design principles and technologies for buildings is one of the most effective approaches to achieving sustainable development [11].

There are still a large number of traditional dwellings in nearly one-third of the mountainous areas in China [12-14]. Mountain villages are a perfect integration of humanity and 
nature, and they reflect the local peoples' principle of adapting themselves to nature for survival and development. During long-term development and evolution, mountain dwellings have gradually developed unique adaptation strategies to cope with the local climate based on climatic, cultural, and social factors; to a certain extent, these have achieved a balance with the natural environment. Several researchers are studying residential dwellings in various regions [15-23]. Xu et al. (2019) [24] conducted a comparative study on the climate adaptation of traditional residential environments in the Qinba Mountains and proposed an effective climate adaptation strategy for traditional earth dwellings. Zeng et al. (2017) [25] studied the influence of traditional village layouts on wind environment and the adaptation of Lingnan traditional village layouts to regional climate; they found that the residential space in the middle of a traditional building layout maintained a good thermal comfort environment. Zhang et al. (2016) [26] studied the response measures and passive design strategies formed by the open interface of the residential interface in the Suzhou region during long-term adaptation to the regional climate. Zhu et al. (2019) [27] qualitatively studied the climate response characteristics of cliff-side kilns in the cold region of China. Meghedy et al. (2016) [28] compared two types of cliff residential earthen bunker buildings; Maymand's building climate adaptation and proper earth heat-use behavior were better than Kandovan's, which exhibited better natural ventilation and daylight use. Ahmed et al. (2021) [29] studied the impact of climate-responsive design on the thermal and energy performance of housing in a hot region of southern Algeria and analysed the passive strategies and parameters of seven different scenarios with modified impact. Amin et al. (2018) [30] studied climate-responsive solutions used in traditional homes in the southwestern Iranian city of Bushehr and analysed the impact of these solutions on the thermal comfort and energy consumption of these buildings compared to modern buildings. Exploring regional design strategies applied to traditional dwellings and applying them to the renovation of existing and new dwellings will help energy conservation and sustainable development in the country, and will provide insights for the construction of dwellings in other regions.

Dong villages are located in southwest China and are under the jurisdiction of Guizhou Province, Guangxi Zhuang Autonomous Region, and Hunan Province. They represent a traditional human settlement lifestyle, featuring the Dong people's adaptation to nature and harmonious coexistence with the environment, in addition to an outstanding example of the Dong people's sustainable utilisation of land and resources over the millennium. They are a manifestation of the Dong people's wisdom, generated during long-term production and living, and the precious heritage of traditional agricultural civilisation in the mountainous area.

\section{Methodology}

\subsection{Theoretical Foundations}

Hippocrates [31] first mentioned the concept of eco-climate 2000 years ago, and in the early 1960s, Victor Olgyay [32] first proposed the design theory of 'bioclimatic regionalism', combining architectural design with climate, region, and human biological comfort in a systematic manner. With increase in global problems such as climate change, resource depletion, and serious pollution, ecological climate theory and 'bioclimatic regionalism' theory have gained importance and play a positive guiding role. Alger believes that architectural designs should follow basic bioclimatic design principles to enable management of the influence of some climatic elements on building and structural design. The bioclimatic theory is based on local architecture and observes the specific environmental characteristics of buildings. In this optimal manner, the construction industry can operate cost-effectively and sustainably [33-35]. Traditional residential buildings in India's composite climate [36,37], Yaodong dwellings in China's Loess Plateau region [38,39], and stilt houses in tropical regions such as Thailand, Laos, Cambodia, Hawaii, and Guam are good examples of the implementation of this theory [40]. 


\subsection{Research Area}

The ancestors of the Dong people can be traced to the ancient "Baiyue" ethnic group. Dongs are arguably the most architecturally sophisticated ethnic group in southern China. Ethnographers base their cultural division of the Dongs on language, which is the basis for the names 'South Dong' and 'North Dong'. Based on the dialect, the Dong people are divided into two dialect regions, the North Dong and the South Dong, bounded by Qimeng Town and Ba Dong Town in Jinping County, Guizhou Province. The North Dong region includes the north of Jinping County in Guizhou Province, Huitong County, Xifeng County, Zhijiang County in Hunan Province, and the western part of Hubei Province (Figure 1). The way of life of the residents of the North Dong is considerably different from that in the South Dong; therefore, the architectural forms and structures of the villages are also substantially different. The most typical feature is that there are no public buildings such as drum towers, gates, and pavilions in the North Dong. The main geographical features of settlements in the North Dong are mountains and hills, with altitudes between 150 and $500 \mathrm{~m}$; for example, the average altitude of the settlement in Huitong County is approximately $500 \mathrm{~m}$, and the average slope is approximately $20-40^{\circ}$. The weather is mostly wet, rainy, and hot in summer and wet and cold in winter. The annual precipitation is 1000-1600 mm, mostly from June to September. The average temperature in the coldest months is $0-10{ }^{\circ} \mathrm{C}$, and the average relative humidity is approximately $80 \%$. Natural ventilation is employed to cool and dehumidify dwellings during the hot and humid summer months. Heating measures are required due to the high humidity in winter and the cold and wet indoor environment.

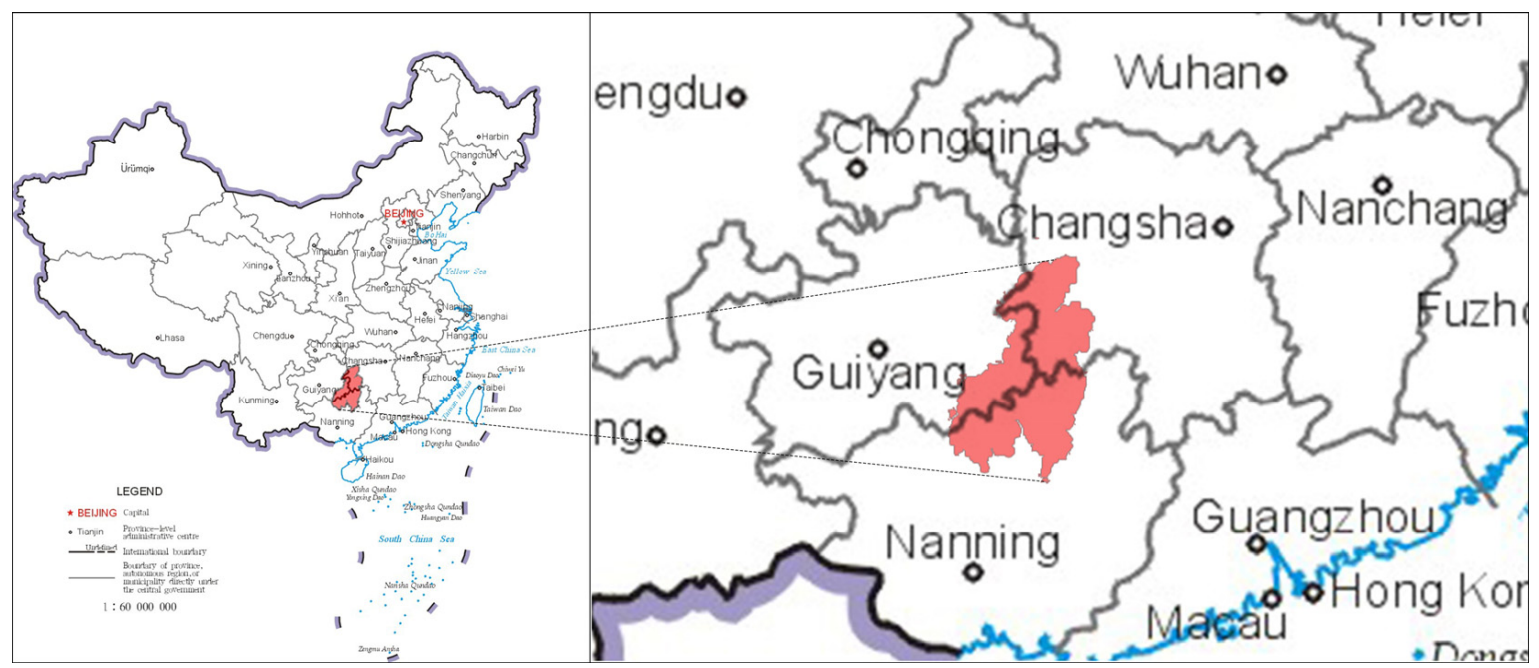

Figure 1. Main location of the Dong ethnic group in China.

\subsection{Qualitative Analysis}

Characters of Traditional Dwellings

The Qixi Village, located in Huitong County, Hunan Province, is a typical traditional village in the North Dong region. Located in the Xuefeng Mountain area at the edge of the Yunnan-Guizhou Plateau, the Qushui River traverses the whole territory from south to north, with the Baima Creek running from west to east and the Anshun Creek running from east to west to join the Qushui River. Figure 2 shows the layout of Qixi Village. It is an example of the typical residential dwellings and culture type in the North Dong region in many aspects, such as natural environmental conditions, dwelling characteristics, and unique customs. 


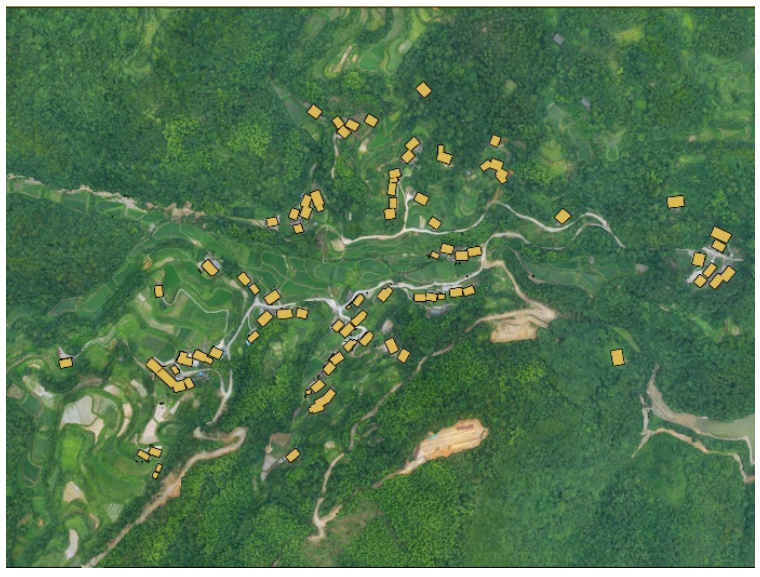

Figure 2. Layout of Qixi Village.

- Villages layout

Table 1 shows the general layout of villages in the North Dong area. The layout with mountains is the most dominant type in the Dong region. Most traditional villages in the North Dong area are surrounded by mountains and are naturally derived (Figure 3). There are no public buildings in these villages, and there is no drum tower, which is the most central building in the South Dong area. The topography of the villages is mostly mountainous; thus, the dwellings are generally arranged along the contour lines. Due to the higher terrain, sunlight and ventilation are better. However, rivers and wells are built in the mountain washes outside the fortress, which is not convenient for water and not conducive to fire fighting.

Table 1. General layout of villages in the North Dong area.

\begin{tabular}{|c|c|c|c|}
\hline Villages & Band Distribution & Cluster Distribution & $\begin{array}{l}\text { Natural Derivation } \\
\text { with Mountains }\end{array}$ \\
\hline Dazhai & & & $\bullet$ \\
\hline Zhongzhai & $\bullet$ & & \\
\hline Jizhai & & $\bullet$ & \\
\hline Hejiatian & & & $\bullet$ \\
\hline Dixi & & & $\bullet$ \\
\hline Chongshou & & & $\bullet$ \\
\hline Jincan & & & $\bullet$ \\
\hline Qixi & & & $\bullet$ \\
\hline Jiuzhai & & & $\bullet$ \\
\hline Moxiu & & & $\bullet$ \\
\hline
\end{tabular}
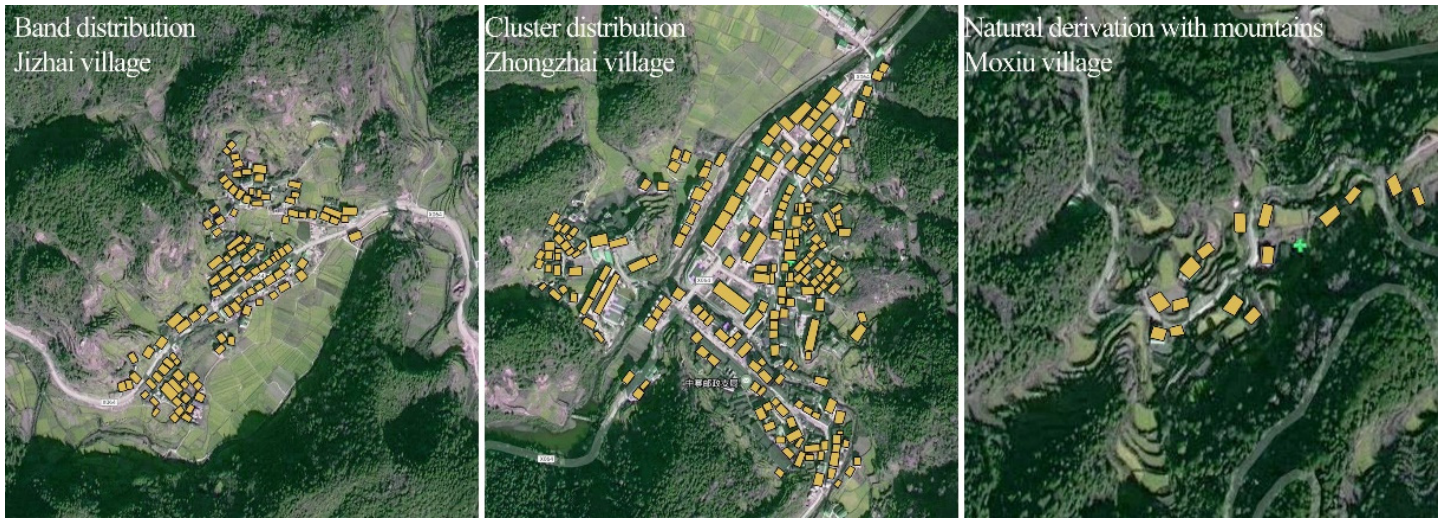

Figure 3. General layout of traditional villages in the North Dong area. 
- Dwelling layout

\section{(1) Dwelling form}

In the typical layout of North Dong dwellings, the principal room is the centre, with bedrooms on both sides, forming a pattern of 'one bright and two dark', as shown in Figure 4a. The fire pit and bedrooms are concentrated along with the depth, resulting in a large depth of the dwelling plan. In some dwellings, in the traditional layout of 'one bright and two dark', attached rooms are added on both sides in front of the main house. A door cover, a simple gatehouse with a simple structure and shape, and an enclosure are set directly opposite the main house to enclose a triple compound (Figure $4 \mathrm{~b}$ ). The residents believe that 'a circle in front of the house is unlucky, and a warehouse behind the house is not peaceful'. Therefore, the storage space is typically placed on the second floor or on a side of the dwelling.

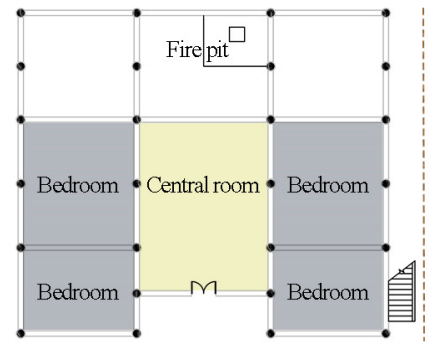

(a)

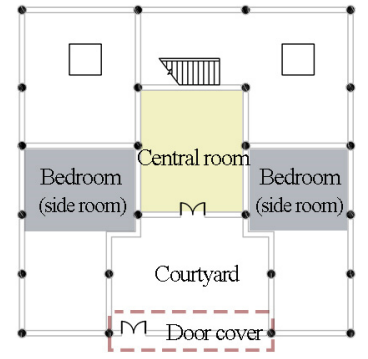

(b)

Figure 4. (a) "One light, two dark" type of traditional dwelling layout. (b) Triad type of traditional dwelling layout.

\section{(2) Dwelling structures}

The structures of traditional dwellings in the North Dong area typically comprise beam-type frames, forming a load-bearing structure with columns and beams. Traditionally, the North Dong has ground-level dwellings, with mainly one- and two-story houses. In two-story residences, the ground floor houses living areas and the upper floors house storage areas. The entrance and the main living space occupy a large area as they are on the ground level, and excavation is typically used to level the foundation. As the geographical environment is mostly mountainous, most of the dwellings are built following the trend of contour lines to reduce the amount of earthwork (Figure 5). Owing to this distribution, dwellings in the North Dong villages have relatively regular forms and their overall layouts are relatively homogeneous.

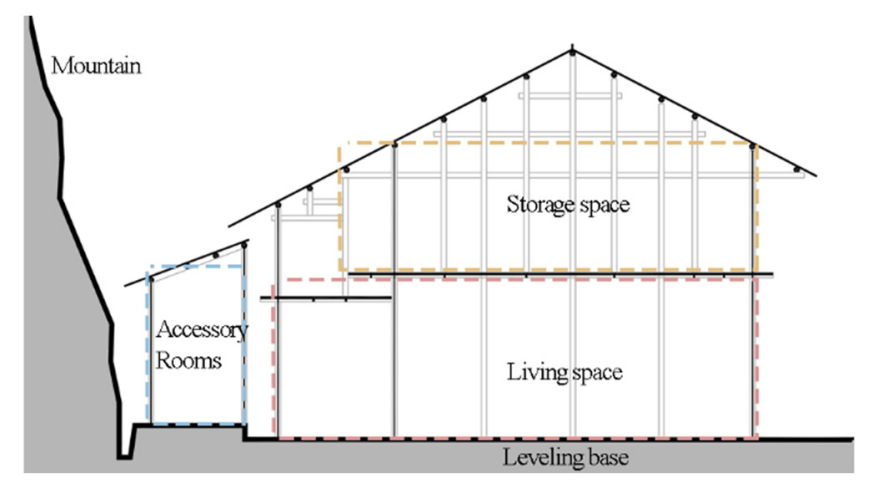

Figure 5. Schematic diagram of a dwelling built according to the trend of contour lines.

The storage space is an elevated space on the upper level, creating a well-ventilated environment suitable for grain storage and reducing solar radiation on the lower level. In some houses, the eaves of the second floor of a residential house are generally higher at the 
front than at the back, which influences the depth of the storage space on the second floor and is beneficial for the shading of the first floor. The roof frame structure of residential houses is typical to this region (Figure 6), making it a unique building style in the North Dong area.

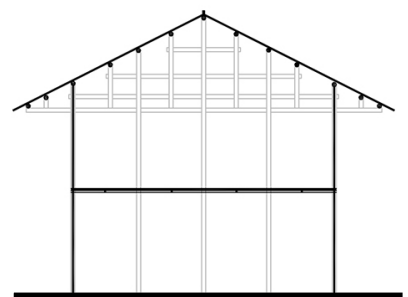

(a)

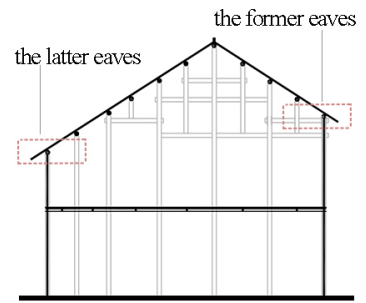

(b)

Figure 6. (a) Roof frame structure of a dwelling with the same height of the former and the latter eaves. (b) Roof frame structure of a dwelling with the former eaves higher than the latter eaves.

\section{(3) Dwelling materials}

Traditional dwellings in the North Dong area often use local natural wood, stone, and clay, and thus have strong regional characteristics. As building materials are difficult to transport, North Dong dwellings adopt the rich local wood resources, resulting in a unique mountainous architectural style. Exterior and interior walls are made of wood. Stones are mainly used for building foundations and pavements, while for masonry, stones are chipped to obtain smooth surfaces. The roof is covered with small green tiles.

\subsection{Quantitative Analysis}

\subsubsection{Objective Measurement}

A typical dwelling located in Qixi Village, Huitong County, Hunan Province was selected to access its indoor physical environment. The dwelling was built some time in 1970-1980; it still retains its original form and construction without any alteration and modification. It shows a typical 'one brightness with two darkness' dwelling layout characteristic of the North Dong area. The dwelling faces south and has three principal rooms divided by partition walls. The living room is in the middle, and is used for receiving visitors. There are two bedrooms on the sides; one of them has a kitchen and a storage room towards the north (Figure 7). The main enclosed structure of the North Dong dwelling includes $400 \mathrm{~mm}$ wooden walls (exterior and interior) with a thermal conductivity coefficient of $\mathrm{k}=0.11 \mathrm{~W} /(\mathrm{m} \mathrm{K})$. C20 fine aggregate concrete $(60 \mathrm{~mm})$ is used for flooring, and fir rafters covered by gray tiles are used for the roof. Exterior windows are single-glass wooden windows, and the doors are $1.2 \mathrm{~m} \times 2.0 \mathrm{~m}$ timber doors with transoms on top; these are kept open during the daytime.

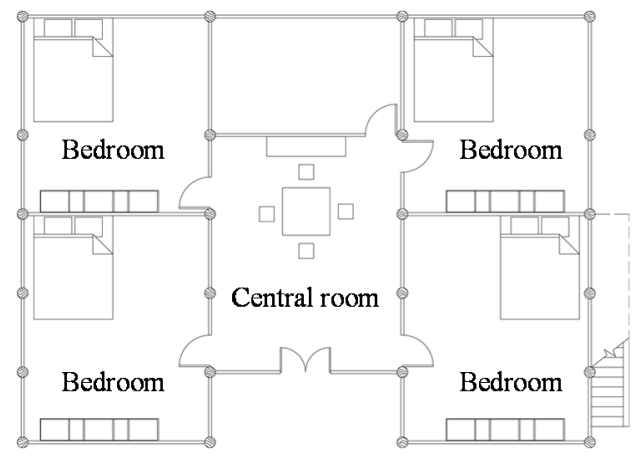

First floor plan

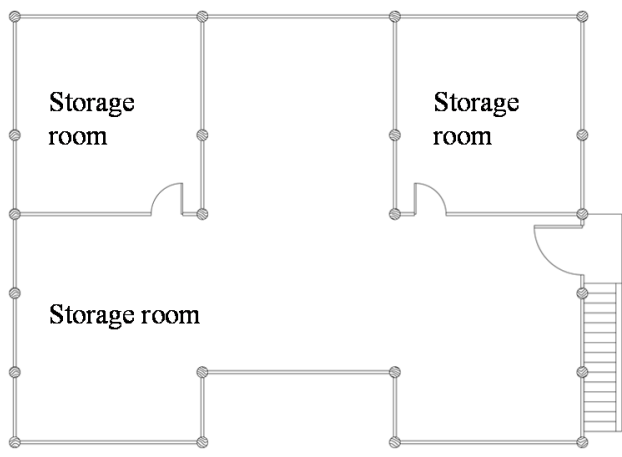

Second floor plan

Figure 7. Floor plan of a sample residential dwelling in Qixi Village. 


\subsubsection{Measurement Setup}

Field measurements were taken to study the climate adaptation of the North Dong dwelling. We gathered data for 91 consecutive days during winter from 6 December 2019 to 6 February 2020. A Testo175H1 (measurement accuracy: $\pm 0.4{ }^{\circ} \mathrm{C} \pm$ digit, $\pm 2 \%$ RH (2-98\% $\mathrm{RH})$, measurement range: $\left.-20 \pm 55{ }^{\circ} \mathrm{C}, 0-100 \% \mathrm{RH}\right)$ was used to automatically record every $10 \mathrm{~min}$ (Figure 8). The monitoring points were located in the bedroom, the centre of the living room $1.5 \mathrm{~m}$ from the ground, and the centre of the outdoor courtyard.

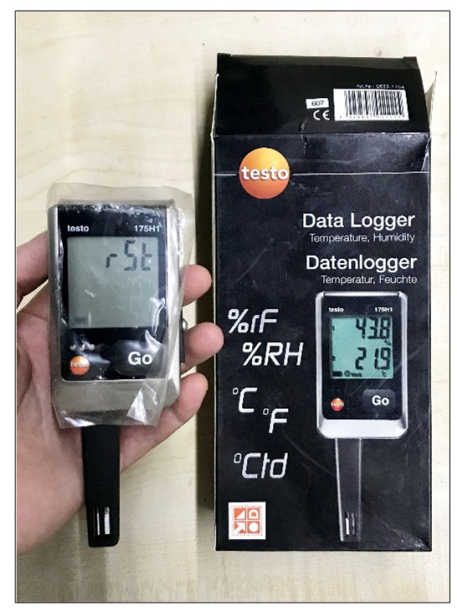

Figure 8. Air temperature and relative humidity monitoring instrument.

\subsubsection{Objective Simulation}

The simulation software, Ecotect Analysis (2011) [24], was chosen for this research based on the measurement data. Firstly, the degree of climatic adaptation of the materials traditionally used in the residences of the North Dong region was studied. The study simulated the indoor physical environment of a typical dwelling using three building materials: wood, raw earth, and brick (Figure 9). Wood is the most prevalently used building material for traditional houses in the region, whereas brick is the predominant building material used in newly constructed dwellings. Raw earth exhibits good thermal insulation properties and is commonly used in dwellings worldwide. Secondly, the degree of climatic adaptation of the structural forms of traditional dwellings in the North Dong region was studied. For a single dwelling, the research model simulated settlements with different structures above and below. The data is shown in Figure 10 and Table 2.

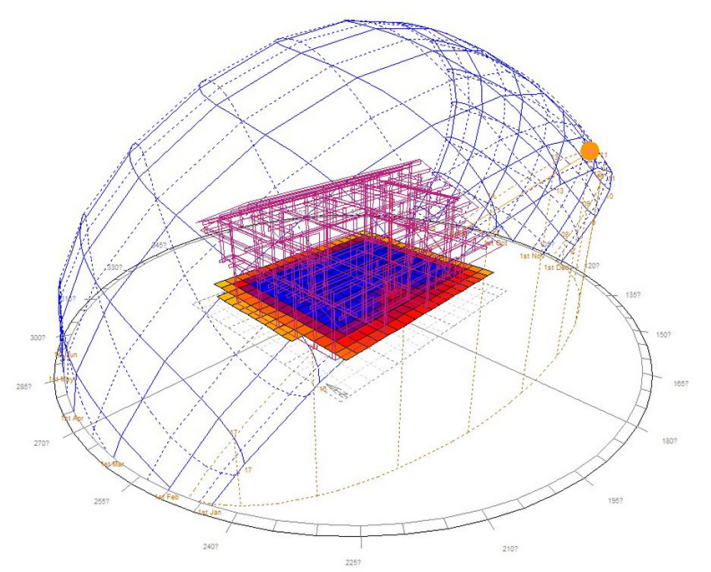

Figure 9. Computer model of the dwelling model. 


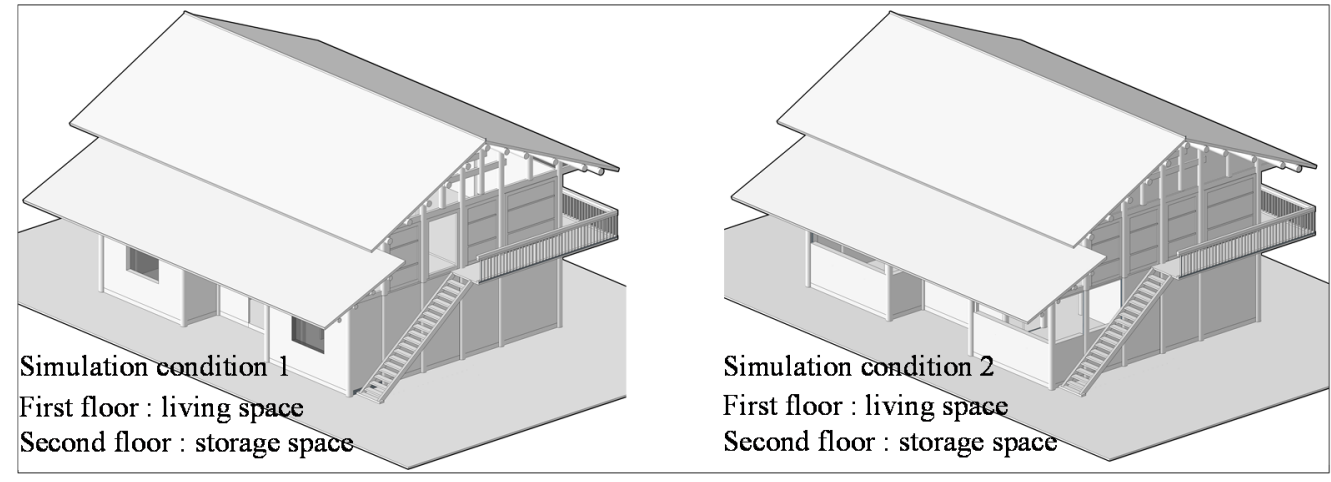

Figure 10. Dwelling model using different settlement forms on upper and lower levels.

Table 2. Indoor and outdoor average humidity and high-frequency humidity range.

\begin{tabular}{|c|c|c|c|c|c|c|}
\hline \multirow[b]{2}{*}{ Type } & \multirow[b]{2}{*}{$\begin{array}{l}\text { Building } \\
\text { Envelope }\end{array}$} & \multirow[b]{2}{*}{ Construction Method } & \multicolumn{4}{|c|}{ Material Thermal Index } \\
\hline & & & $\begin{array}{l}\text { Thickness } \\
\text { (mm) }\end{array}$ & $\begin{array}{l}\text { Density } \\
\left(\mathrm{kg} / \mathrm{m}^{3}\right)\end{array}$ & $\begin{array}{l}\text { Specific Heat } \\
\text { kJ/(kg K) }\end{array}$ & $\begin{array}{c}\text { Heat } \\
\text { Conductivity } \\
\text { W/(m K) }\end{array}$ \\
\hline \multirow[t]{12}{*}{ Wood structure } & \multirow{4}{*}{$\begin{array}{c}\text { Wooden Wall } \\
\text { Wooden partition } \\
\text { wall }\end{array}$} & Wooden board & 30 & 500 & 2510 & 0.17 \\
\hline & & 1. Wooden board & 15 & 500 & 2510 & 0.17 \\
\hline & & 2. Air layer & 30 & 1.3 & 1004 & 0.0023 \\
\hline & & 3. Wooden board & 15 & 500 & 2510 & 0.17 \\
\hline & Door & Wooden door & 40 & 550 & 2301 & 0.343 \\
\hline & \multirow[t]{3}{*}{ Floor } & $\begin{array}{l}\text { 1. C20 fine aggregate } \\
\text { concrete }\end{array}$ & 60 & 2300 & 920 & 1.51 \\
\hline & & 2. Soil pile & 150 & 1600 & 1010 & 0.81 \\
\hline & & 3. 3:7 Lime-soil & 300 & 1795.6 & 884 & 0.72 \\
\hline & Window & $\begin{array}{l}\text { Single-glass wooden board } \\
\qquad \mathrm{K}=4.7\left(\mathrm{~W} / \mathrm{m}^{2} \mathrm{~K}\right)\end{array}$ & & & & \\
\hline & Roof & 1. $15 \mathrm{~mm}$ gray tile roof & 15 & 2044 & 1050 & 0.96 \\
\hline & & 2. Rafters & 80 & 2300 & 656.9 & 0.753 \\
\hline & & 3. Purlin & 100 & 2300 & 656.9 & 0.753 \\
\hline \multirow[t]{7}{*}{ Brick structure } & \multirow[t]{3}{*}{ Brick wall } & 1. Lime cement & 15 & 1800 & 1050 & 0.93 \\
\hline & & 2. Clay brick & 240 & 1800 & 1050 & 0.81 \\
\hline & & 3. Lime cement coating & 15 & 1800 & 1050 & 0.93 \\
\hline & \multirow[t]{3}{*}{ Partition wall } & 1. Lime cement & 15 & 1800 & 1050 & 0.93 \\
\hline & & 2. Clay brick & 120 & 1800 & 1050 & 0.81 \\
\hline & & 3. Lime cement coating & 15 & 1800 & 1050 & 0.93 \\
\hline & \multicolumn{2}{|c|}{ Door/Floor/Roof/Window } & \multicolumn{4}{|c|}{ Same structure as the wood } \\
\hline \multirow[t]{4}{*}{ Earth structure } & \multirow[t]{3}{*}{$\begin{array}{l}\text { Rammed earth } \\
\text { wall }\end{array}$} & 1. Cement mortar float & 15 & 1800 & 1050 & 0.93 \\
\hline & & 2. Rammed earth wall & 400 & 1800 & 1010 & 0.76 \\
\hline & & 3. Lime cement coating & 15 & 1600 & 1050 & 0.81 \\
\hline & \multicolumn{2}{|c|}{ Door/Floor/Roof/Window } & \multicolumn{4}{|c|}{ Same structure as the wood } \\
\hline
\end{tabular}

\section{Results}

\subsection{Measurement Results}

\subsubsection{Temperature}

Figure 11 shows the monitoring results for the indoor and outdoor temperatures and humidity of typical dwellings in the North Dong area. Table 3 shows the indoor and outdoor average temperatures, along with the high-frequency temperature range. During monitoring, the average outdoor temperature was $-8.32{ }^{\circ} \mathrm{C}$. The monthly lowest average temperature of $6.32{ }^{\circ} \mathrm{C}$ was noted during January; this temperature is $0.7^{\circ} \mathrm{C}$ and $1.2^{\circ} \mathrm{C}$ lower than that of the living room and bedroom, respectively. The monthly highest outdoor 
temperature amplitude was $22.7^{\circ} \mathrm{C}$, which is $5.6^{\circ} \mathrm{C}$ lower than that of the living room and $4.4^{\circ} \mathrm{C}$ higher than that of the bedroom. Furthermore, the monthly highest high-frequency outdoor temperature was $8.2^{\circ} \mathrm{C}$, which is the same as that of the living room and $2.4{ }^{\circ} \mathrm{C}$ lower than that of the bedroom.

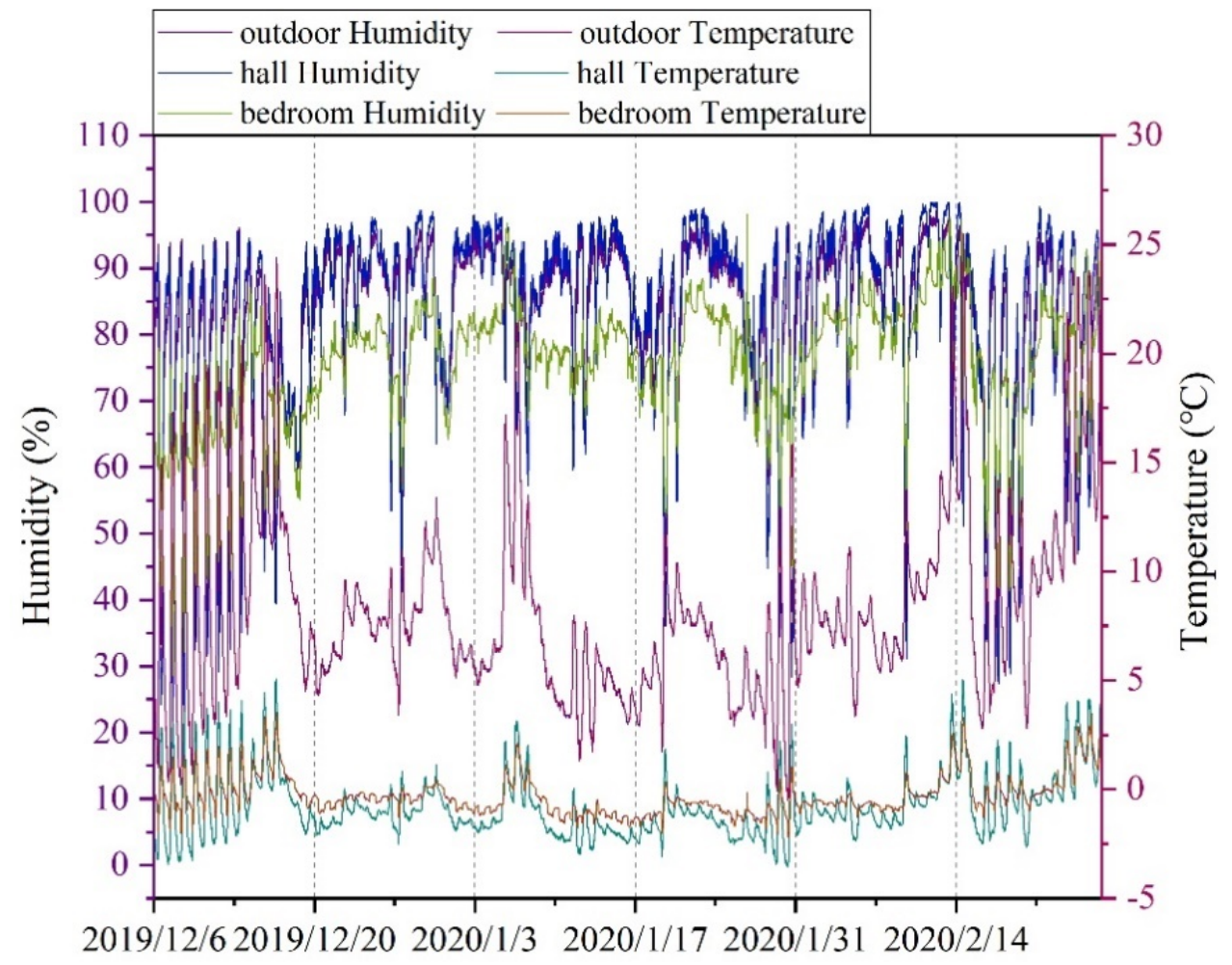

Figure 11. Indoor and outdoor temperature and humidity.

Table 3. Indoor and outdoor average temperatures and high-frequency temperature range.

\begin{tabular}{|c|c|c|c|c|c|c|c|c|c|}
\hline \multirow[b]{2}{*}{ Month } & \multicolumn{3}{|c|}{ Outdoor $/{ }^{\circ} \mathrm{C}$} & \multicolumn{3}{|c|}{ Living Room $/{ }^{\circ} \mathrm{C}$} & \multicolumn{3}{|c|}{ Bedroom $/{ }^{\circ} \mathrm{C}$} \\
\hline & Average & Range & $\begin{array}{c}\text { High } \\
\text { Frequency }\end{array}$ & Average & Range & $\begin{array}{c}\text { High } \\
\text { Frequency }\end{array}$ & Average & Range & $\begin{array}{c}\text { High } \\
\text { Frequency }\end{array}$ \\
\hline December & 8.85534 & $0.2-24.4$ & 8.2 & 9.50433 & $0-28.1$ & 8.2 & 11.29332 & $4.8-23.1$ & 10.6 \\
\hline January & 6.31902 & $-0.5-21.4$ & 5.6 & 6.81295 & $-0.2-21.8$ & 5.7 & 8.7649 & $4.1-18.4$ & 7.9 \\
\hline February & 10.19203 & $2.8-25.5$ & 8.8 & 10.93285 & $2.7-28$ & 7.8 & 11.82464 & $7.2-22.9$ & 9.5 \\
\hline Winter & 8.32034 & $-0.5-25.5$ & 5.5 & 9.01589 & $-0.2-28.1$ & 7.7 & 10.56108 & $4.1-23.1$ & 9.5 \\
\hline
\end{tabular}

The analysis of indoor and outdoor temperatures during the test is shown in Figure 12. The results show that during December, the outdoor temperature exceeded $10{ }^{\circ} \mathrm{C} 63 \%$ of the time, and was $8 \%$ and $11 \%$ lower than that of the living room and bedroom, respectively. During January, the outdoor temperature exceeded $5{ }^{\circ} \mathrm{C} 55 \%$ of the time and was $7 \%$ and $38 \%$ lower than the living room and bedroom, respectively. During February, the outdoor temperature exceeded $10{ }^{\circ} \mathrm{C} 32 \%$ of the time, and was $5 \%$ and $34 \%$ lower than that of the living room and bedroom, respectively. 


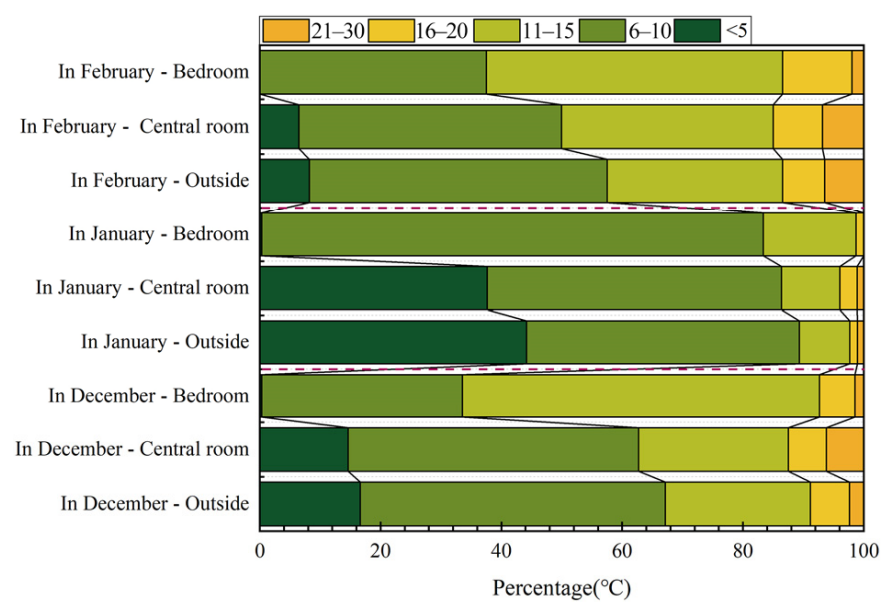

Figure 12. Analysis of indoor and outdoor temperatures.

Figure 13 shows the sine function fitting of the indoor and outdoor temperatures. During the measurement, the temperatures at all monitoring points exhibited a fluctuating trend with a minimum positive period of 0.5 . The living room and bedroom temperatures fluctuated in relation to outdoor temperatures. The amplitude of the fitted curve for outdoor temperature was the largest at 8.6 , followed by 7 for the living room and 3 for the bedroom.

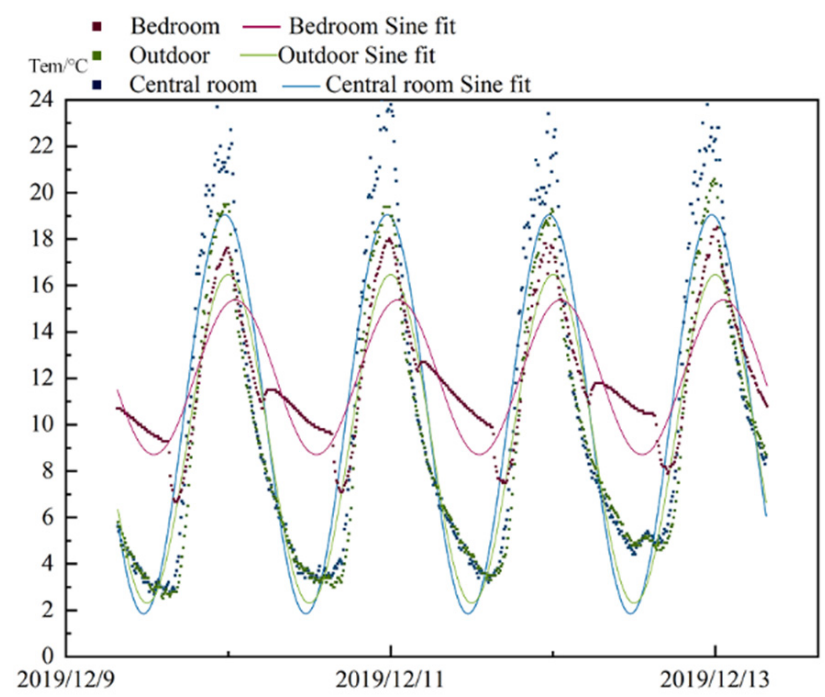

Figure 13. Analysis of indoor and outdoor temperature sine function fitting.

\subsubsection{Humidity}

Table 4 shows the indoor and outdoor average humidity and high-frequency humidity range. In the monitoring duration, the average outdoor humidity was $82.5 \%$. The monthly highest average outdoor humidity of $85.2 \%$ was observed in January and was $0.7 \%$ lower than that of the living room and $2.5 \%$ higher than that of the bedroom. The monthly highest outdoor humidity amplitude was $74.1 \%$, which is $6.3 \%$ lower than that of the living room and $14.1 \%$ higher than that of the bedroom. Moreover, the monthly highest high-frequency outdoor humidity was $90.5 \%$, which is $9.4 \%$ lower than that of the living room and $7.8 \%$ higher than that of the bedroom. 
Table 4. Indoor and outdoor average humidity and high-frequency humidity range.

\begin{tabular}{cccccccccc}
\hline & \multicolumn{3}{c}{ Outdoor/\% } & \multicolumn{3}{c}{ Living Room/\% } & \multicolumn{2}{c}{ Bedroom/\% } \\
\cline { 2 - 9 } Month & Average & Range & $\begin{array}{c}\text { High } \\
\text { Frequency }\end{array}$ & Average & Range & $\begin{array}{c}\text { High } \\
\text { Frequency }\end{array}$ & Average & Range & $\begin{array}{c}\text { High } \\
\text { Frequency }\end{array}$ \\
\hline December & 79 & $22.1-96.2$ & 87.8 & 79.5 & $18.3-98.7$ & 89.3 & 70.8 & $28.6-88.6$ & 78.3 \\
January & 85.2 & $37.3-96.6$ & 90.5 & 86 & $28.3-99.1$ & 93.1 & 77.4 & $44.9-98.2$ & 77.8 \\
February & 82.7 & $32.9-98.7$ & 88.4 & 84.4 & $27.3-99.9$ & 99.9 & 79.4 & $41.3-97.7$ & 82.7 \\
Winter & 82.5 & $22.1-98.7$ & 90.5 & 83.5 & $18.3-99.9$ & 92.6 & 76.1 & $28.6-98.2$ & 82.7 \\
\hline
\end{tabular}

The analysis of indoor and outdoor humidity during the test is shown in Figure 14. The results show that during December, the outdoor humidity exceeded $80 \%$ for $50 \%$, which is $15 \%$ lower than that of the living room and 33\% higher than that of the bedroom. During January, the outdoor humidity exceeded $80 \%$ for $79 \%$, which is $3 \%$ lower than that of the living room and 39\% higher than the bedroom, During February, the outdoor humidity exceeded $80 \%$ for $71 \%$, which is $5 \%$ lower than that of the living room and $13 \%$ higher than that of the bedroom.

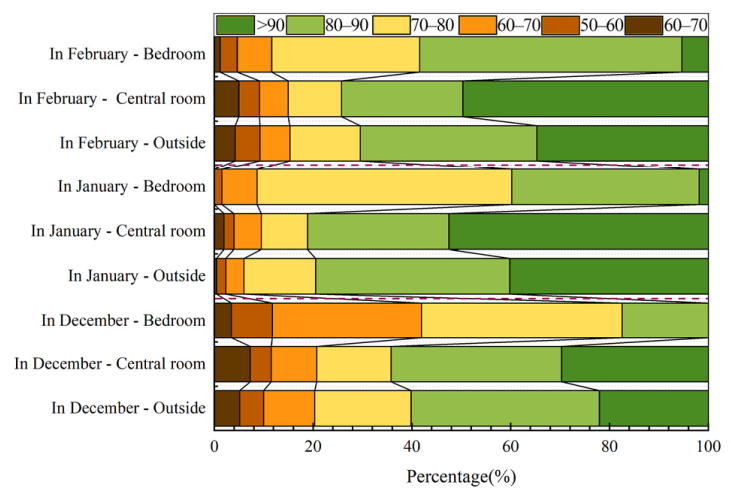

Figure 14. Analysis of indoor and outdoor humidity.

\subsection{Simulation Results}

\subsubsection{Thermal Environment}

The indoor and outdoor temperature simulation results of the residential dwellings with different materials are shown in Figure 15. The results show that during January 21, the indoor temperature fluctuations of the three materials were consistent with the outdoor ones. The indoor temperature fluctuation of the wood-dwelling was the smallest and the insulating effect was the lowest, while the average temperature was not significantly different from that of the brick and raw earth dwelling. The average temperature difference was below $2{ }^{\circ} \mathrm{C}$.

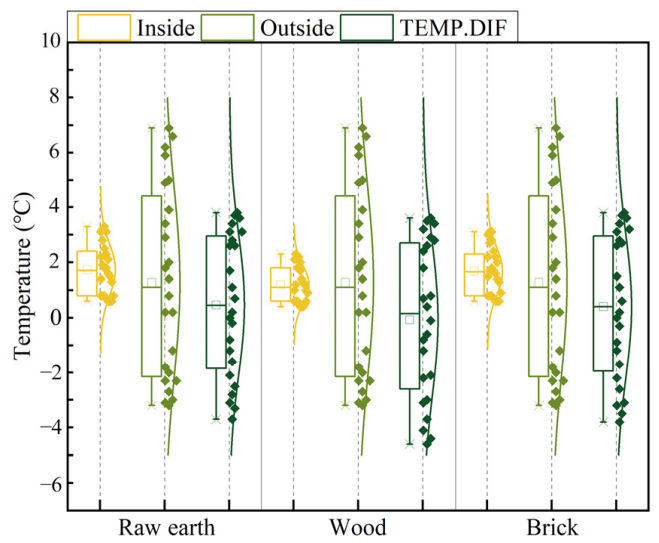

Figure 15. Temperature simulation results for dwellings made of different materials. 


\subsubsection{Wind Environment}

The experiment used a computer to simulate the first and second-floor indoor wind environments of North Dong dwellings with different structural forms on the hottest and coldest days of the year. Meteorological data from the region were employed for the simulation. Figure 16 shows the simulation results of the indoor wind environment in a North Dong dwelling. As we have observed, in summer, the wind speed in the living room of living area condition 1 can reach $0.9 \mathrm{~m} / \mathrm{s}$, while the wind speed in condition 2 is 0 . The highest wind speed in the window position of the storage area condition 1 is $1.5 \mathrm{~m} / \mathrm{s}$. This gives rise to a through wind, which is more effective than the ventilation of condition 1 in summer. In winter, the ventilation in the living area is worse in condition 1 than in condition 2, and the wind speed at the window of the latter is $0.9 \mathrm{~m} / \mathrm{s}$. Furthermore, the ventilation of the storage area is better in condition 1 than in condition 2 . The wind speed in the storage area of condition 1 is $1.5 \mathrm{~m} / \mathrm{s}$, which is $0.3 \mathrm{~m} / \mathrm{s}$ higher than that in condition 2. The structural form of traditional dwellings in the North Dong area is condition 1, with the living area on the ground floor and the storage area on the upper floor. The storage space is located on the upper floor with good ventilation in the summer and winter. These conditions are conducive to the storage of grains and reduce heat radiation in the living space on the ground floor.

Simulated conditions: First floor housing, Second floor storage

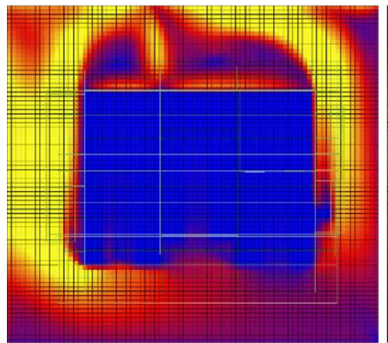

Summer

First floor ventilation

Simulated conditions: First floor storage, Second floor housing

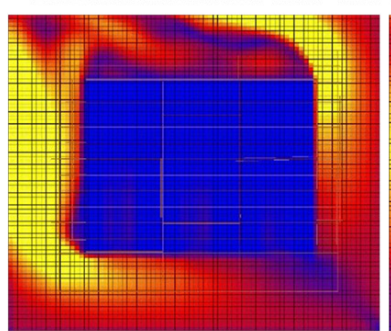

Summer

First floor ventilation

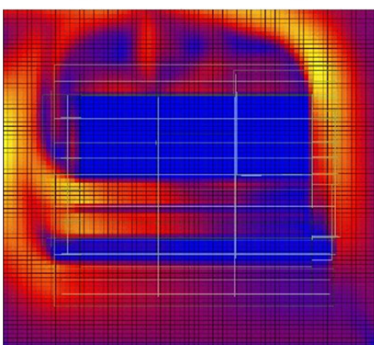

Summer

Second floor ventilation

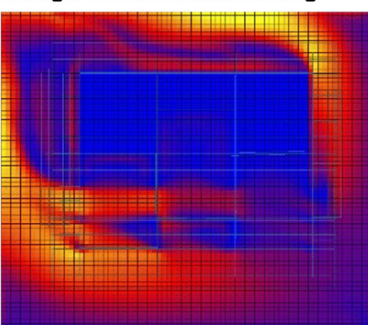

Summer

Second floor ventilation

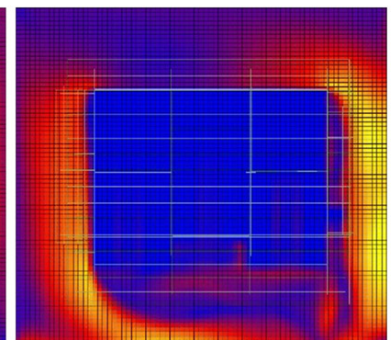

Winter

First floor ventilation

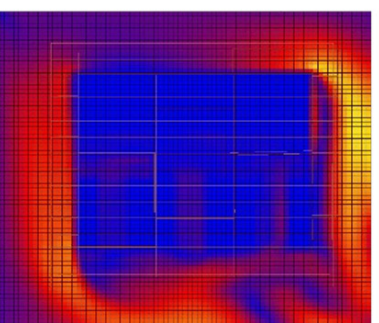

Winter

First floor ventilation

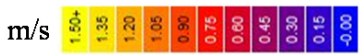

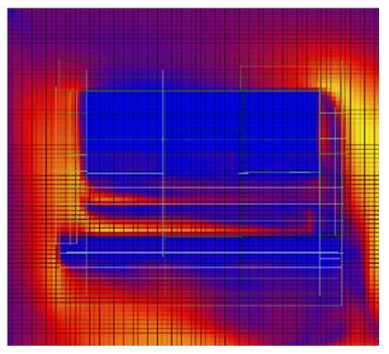

Winter

Second floor ventilation

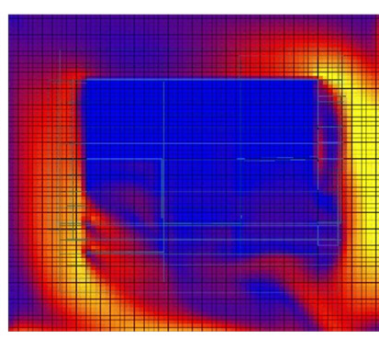

Winter

Second floor ventilation

Figure 16. Simulation of indoor wind environments in a North Dong dwelling.

\subsubsection{Energy Consumption}

The monthly energy-consumption simulation results of residential dwellings with different building materials are shown in Figure 17. Wood dwellings have the lowest energy consumption in the region, with the highest heating energy consumption of $6102 \mathrm{~W}$ on 18 January, which is $758 \mathrm{~W}$ and $1234 \mathrm{~W}$ lower than rammed earth and brick, respectively. Furthermore, the highest cooling energy consumption was $3833 \mathrm{~W}$ on 3 July, which is $30 \mathrm{~W}$ and $1091 \mathrm{~W}$ lower than rammed earth and brick, respectively. Meanwhile, the monthly energy consumption of wood dwellings is lower than that of rammed earth and brick. Simulation results of the annual energy consumption of residential dwellings with the three building materials show that wood-frame dwellings can save up to $26 \%$ and $39 \%$ of energy per year compared to raw earth and brick, respectively. This indicates that the Dong traditional dwellings are built with wood as an adaptation to the local climate. 


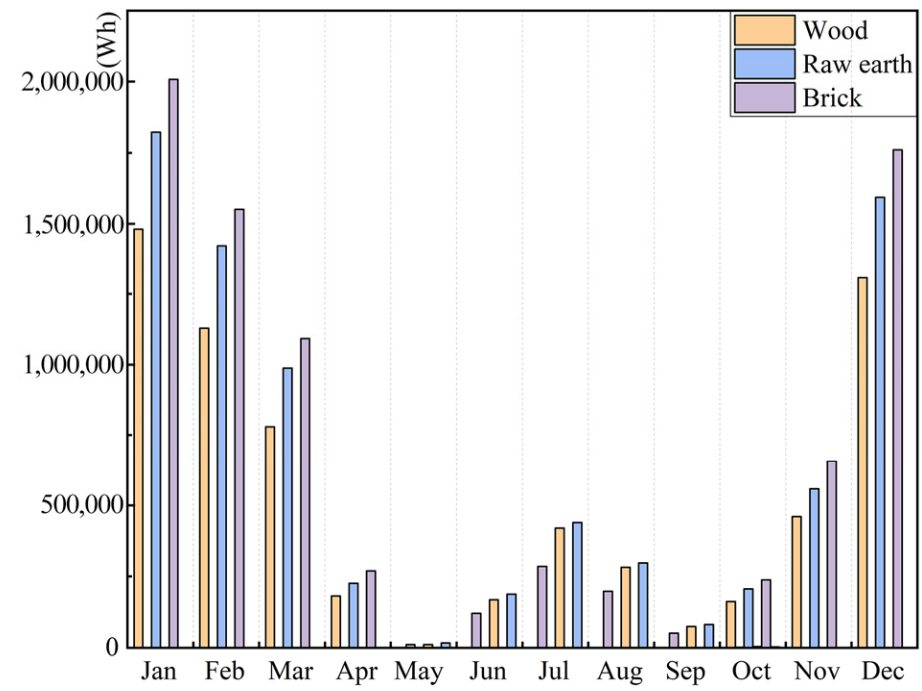

Figure 17. Analysis of simulated monthly energy consumption.

\section{Discussion of Climate Adaptability of Traditional Dwellings}

\subsection{Village Location Adaptability}

The general layout of the villages in the North Dong area is naturally derived and arranged along the contours of the sunny slopes of the mountains, with sufficient sunlight and good ventilation. For the Dazhai Village and Di Xi Village in the North Dong area (Figure 18), the natural geography primarily comprises mountains and valleys without substantial flat land for cultivation. Furthermore, water is needed for cultivation. The slope of the valley is gentle for cultivation, and the fields are arranged in the form of terraces from the valley to the top of the mountain. Houses are built with contours on the high slopes of the mountains so that they can receive more sunlight and better ventilation. Dong people have the traditional concept of "No trees, no ridgepieces; no pillar, no prosperity". The beautiful natural environment of Qixi Village is also ascribed to the fact that the residents plant trees while exploiting the resources of the mountains and forests without destroying them (Figure 19). The concepts behind the village layouts in the North Dong region reflect the symbiotic relationship between humans and nature.
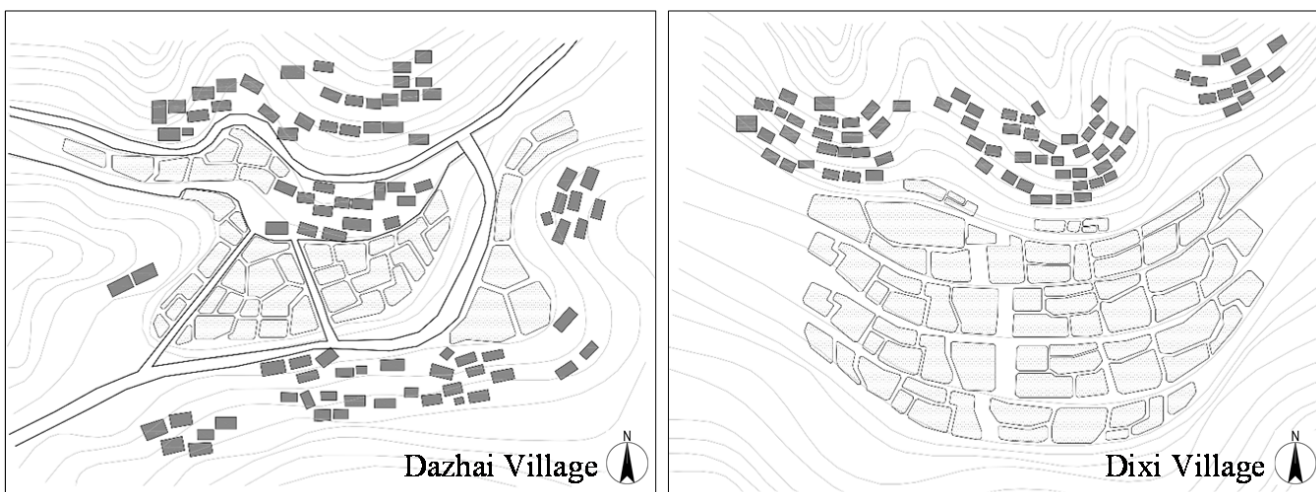

Figure 18. Village locations in the North Dong area. 


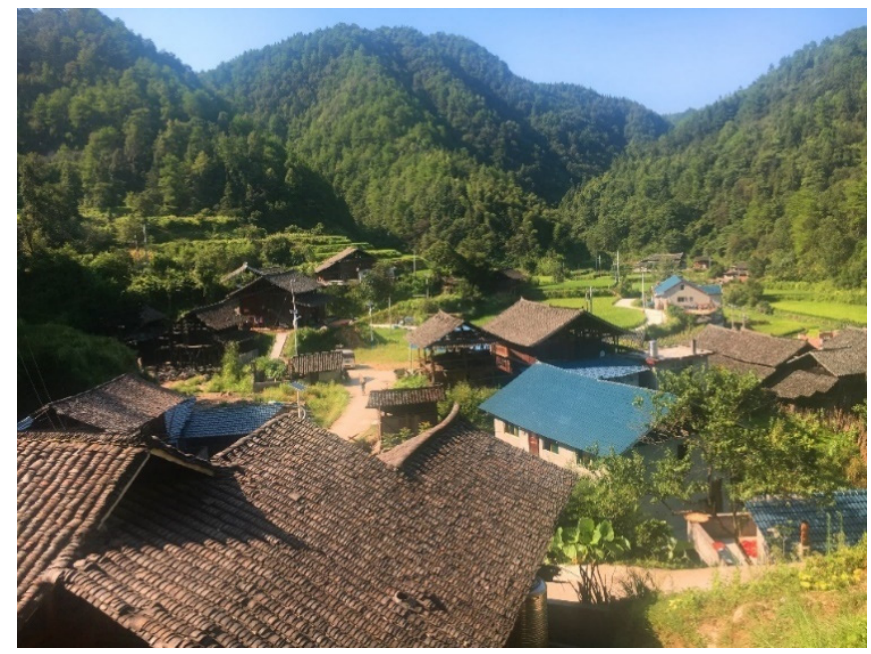

Figure 19. Mountain environment of Qixi Village.

\subsection{Dwelling Adaptability}

\subsubsection{Dwelling Form}

The dwelling form is influenced by natural factors such as the intensity of solar radiation, time of natural light, and the prevailing wind direction, in addition to culture and living habits. The dwellings in Qixi are located on the sunny slope of the mountain, facing south, and are naturally derived along the contour line. The intensity and duration of solar radiation are longer in the south than in the north, which means that the dwellings can make complete use of the sunlight to increase the indoor temperature in winter. Alternatively, wide eaves can be employed to obtain a decent duration and intensity of light in the summer while providing shade from the sun. The main living spaces, such as the hall and master bedroom, are located in the southern part of the floor plan in the ground floor living layout, which ensures that the main living spaces are subject to good lighting and ventilation. Considering the local wind environment, the dwellings have no windows facing north, thus effectively avoiding the influence of the prevailing northwest wind on the interior in winter (Figure 20).
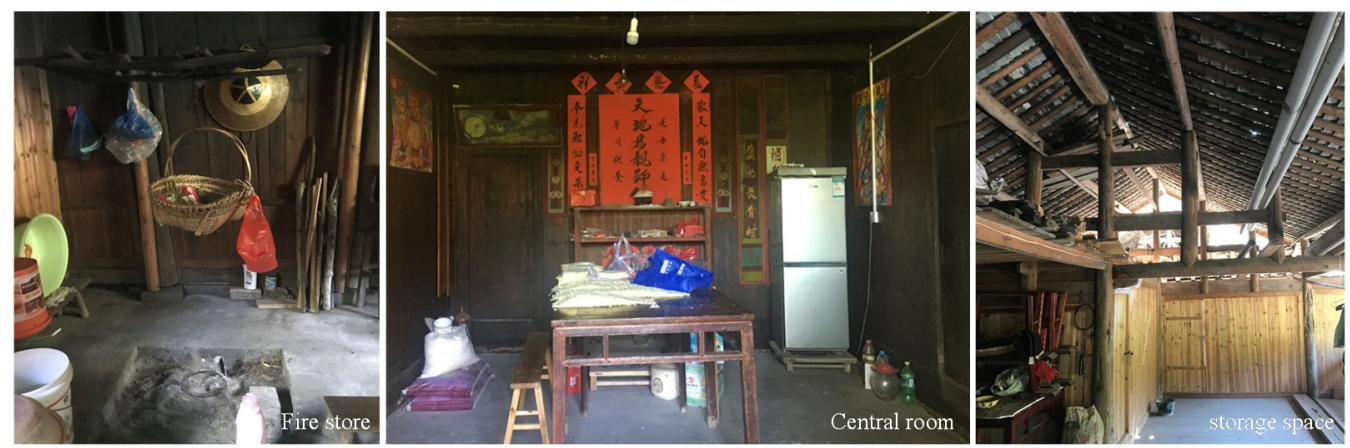

Figure 20. Main rooms of a traditional dwelling in the North Dong area.

\subsubsection{Dwelling Structure}

The structure of residential dwellings depends on environmental factors such as temperature, rainfall, and wind speed, which are mainly reflected in roof type and living style. Qixi Village is located in the hot summer and cold winter climate zone, with high temperatures and rain in the summer and cold and wet winters, indicating a subtropical monsoon climate type. The dwellings are generally two-storeyed and mainly ground-type. The living area for daily life is set on the ground floor, and the rooms for storage and occasional living are set on the upper floor. The space on the upper floor is elevated and has good ventilation to reduce humidity and temperature for storage. Simultaneously, it 
also plays a role in heat insulation for the living space on the ground floor. The living space is located on the ground floor to avoid direct radiation from the sun to the floor, which can help reduce the indoor temperature. The roof type of the house is double-roofed with sloping eaves, which can aid in rapid drainage of the rainwater, and the wide eaves can significantly reduce the erosion of wood and sunlight from rainfall (Figure 21).

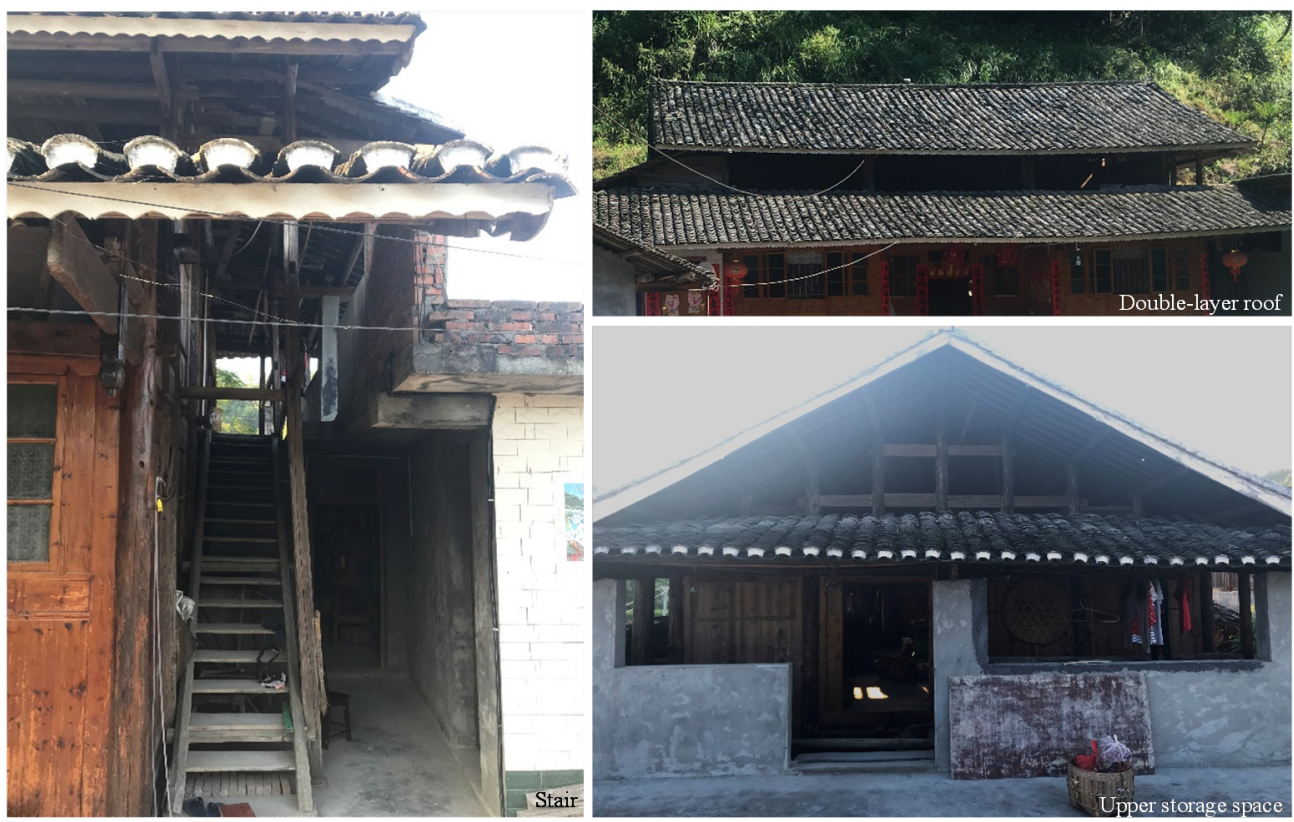

Figure 21. Dwelling structure in the North Dong area.

\subsubsection{Dwelling Materials}

Figure 22 shows the dwelling materials used in the North Dong area. And Table 5 shows the characteristics of residential materials. The roofs of the dwelling are covered with green tiles on wooden purlins, which can be obtained directly from the mountainous area of Qixi Village. The green tiles are made of clay, with good heat insulation and water resistance, preventing rainwater penetration and direct solar heat transfer into the dwelling. In addition to the convenience and low cost of wood, it also has the advantages of being green, pollution-free, and having good air permeability. This keeps the indoor air fresh and balances the humidity to create a comfortable indoor environment.
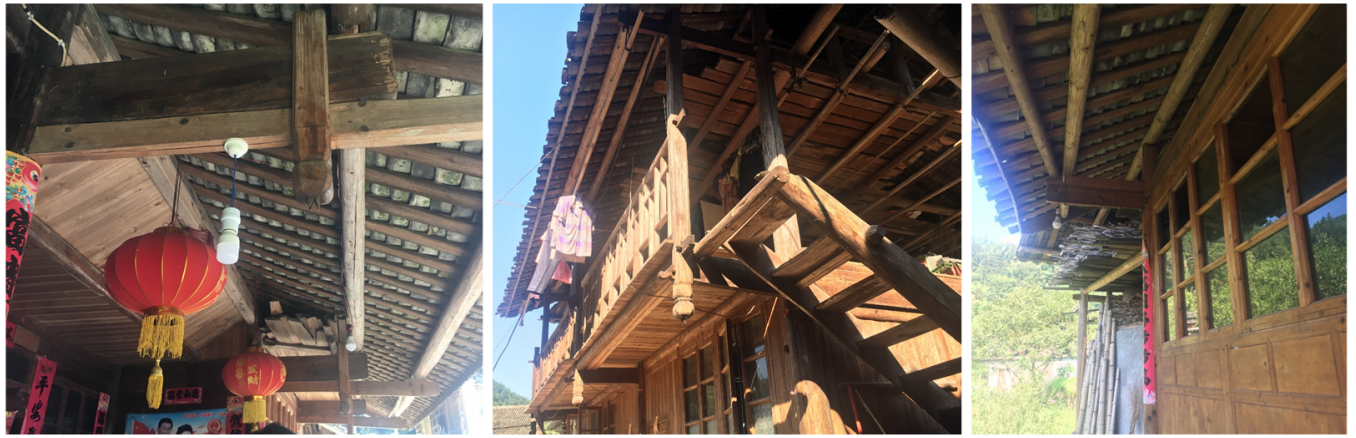

Figure 22. Dwelling materials used in the North Dong area. 
Table 5. Characteristics of residential materials.

\begin{tabular}{cccc}
\hline Material & Building Structure & Purchasing Method & $\begin{array}{c}\text { Heat Conductivity } \\
\text { W/(m K) }\end{array}$ \\
\hline Wood & Wall, Door, Floor, Window & Homemade & 0.17 \\
Rammed earth & Floor & Homemade & 0.93 \\
Glass & Window & Market Purchase & 4.70 \\
Stone & foundation & Homemade & 0.7 \\
Concrete & Floor & Market Purchase & 1.51 \\
Green tile & Roof & Homemade & 0.96 \\
\hline
\end{tabular}

\section{Conclusions and Suggestions}

Traditional dwellings are built through the process of understanding the natural and human environment they are set in. This study investigates climate-responsive solutions used in traditional dwellings in the North Dong region, combining qualitative and quantitative analyses. The characteristics of traditional dwellings in the North Dong region were investigated, including the village layouts, dwelling forms, dwelling structures and dwelling materials. Moreover, the indoor temperature and humidity variation characteristics of traditional dwellings in Qixi Village were analysed by selecting various samples of dwellings in the local climate throughout the year and short-term on-site indoor physical environment measurements. The simulation software Ecotect Analysis (2011) was selected to analyse the indoor physical environment and the energy consumption of the sample dwellings under different working conditions. It is evident from the results that the traditional dwellings in the North Dong region reflect the concept of harmony between human and nature. These traditional dwellings can be well adapted to the local climate in terms of form, material and structure.

\subsection{Conclusions}

According to the results of the measurements and simulations, the form, structure, and material aspects of the dwellings have a significant impact on the indoor thermal environment and energy consumption. Dong traditional dwellings are adapted to the local climate in terms of dwelling form, structure, and materials.

(1) The measurement results show that the temperature fluctuations in the bedroom and hall of a typical residential dwelling in the North Dong area in winter are $4.4{ }^{\circ} \mathrm{C}$ and $5.6{ }^{\circ} \mathrm{C}$ lower than outdoor temperature fluctuations. Moreover, the average indoor temperature is approximately $1{ }^{\circ} \mathrm{C}$ higher than that of the outdoors. The lowest amplitude of temperature fitting curve is found in the bedroom, which is lower than that of the outdoor by 5.3. The average outdoor humidity is $90.5 \%$, which is $7.8 \%$ higher than that of the bedroom. The fluctuation of outdoor humidity is $14.1 \%$ higher than that of the bedroom. Dong traditional houses have a good indoor conditioning ability.

(2) The simulation results show that the wood residential dwellings have the worst thermal insulation performance. The average temperature difference with brick structure and raw earth structure dwellings is not significant, and is within $2{ }^{\circ} \mathrm{C}$. The wind velocities of the residential structures with the living area on the first floor and storage area on the second floor are $0.9 \mathrm{~m} / \mathrm{s}$ and $1.5 \mathrm{~m} / \mathrm{s}$ in the living room and storage room, respectively, in the summer. This is better than the wind environment of the structure form with a replacement function. The monthly energy consumption of wood structure dwellings is also lower than that of dwellings made with raw earth and brick structures. Meanwhile, wood-frame dwellings can save $26 \%$ and $39 \%$ of energy per year compared to raw earth and brick wood structures, respectively.

(3) The traditional dwellings of North Dong are amended to sustain the hot and humid climate of the region, which is an excellent means for local buildings to operate at a low cost and develop sustainably. The general layout of the village is naturally derived from the mountainous landscape. The dwellings are located on the sunny 
slope of the mountain, facing south, with the living space on the first floor and toward the south of the floor plan. Furthermore, the dwellings are sustainably built with locally abundant wood. These construction methods ensure that the dwelling receives sufficient sunlight and good ventilation. Furthermore, the dwelling operates in a low-energy manner while maintaining a good physical environment inside.

\subsection{Suggestions}

It is well known that climatic adaptation strategies for dwellings are the most effective measure to reduce energy consumption and contribute to a healthy indoor environment. This study involves a comparative analysis of the measured indoor environment of a typical residential dwelling in the North Dong region and a simulation of the indoor environment of a dwelling made of wood, brick, and raw earth. The results show that the passive design strategy adopted for traditional dwellings made of wood in the North Dong area effectively adapts to the local climatic environment. However, it is found that the indoor physical environment of the dwelling is still not ideal. The main issues are insulation and heating in winter and thermal insulation and cooling in summer. Improving these aspects will contribute to a healthy indoor environment for other dwellings in the region.

(1) Local traditional dwellings have numerous technical aspects to adapt to the climatic environment, such as small doors and windows, overhead roofs, and wide eaves. The relatively small size of the doors and windows helps reduce heat loss in winter. Measures such as top floor elevation, small windows on the north wall and no windows on the east-west wall are good for insulation. The top floor elevation for storage also reduces the fluctuation of indoor air temperature in the lower residential floors. Furthermore, it provides a good micro-heating environment for small spaces in winter. The wide eaves can effectively drain rainwater to prevent the erosion of timber walls and the absorption of excess heat from exterior walls in summer. In winter, it can provide shade from the sun for the residents. These technical measures should be adopted and improved when designing modern houses.

(2) The self-insulated exterior walls used in the traditional residential dwellings of the North Dong region are single-material exterior walls. We recommend adding $1 \mathrm{~cm}$ of wood grille on the inner side of the exterior wall, along with a 4-cm-thick polyurethane rigid foam, a $1 \mathrm{~cm}$ wood grille, and a $2 \mathrm{~cm}$ cedar board to form a composite wall. This measure can effectively improve the thermal performance of the wall, while simultaneously conserving the original appearance of the interior and exterior of the traditional residential dwelling.

(3) Considering the economic conditions and regional characteristics of the North Dong region, it is more suitable to use thick glass to improve the thermal performance of the windows. The windows of the traditional dwellings in North Dong region consist of two parts: window frame and windowsill, whose sealing performance is extremely poor. We recommend adding the same form of window frame and windowsill on the other side of the original window frame and windowsill. This will ensure that the original appearance of the traditional dwellings is not compromised, and the new window frame will be approximately $10 \mathrm{~mm}$ thicker than the original to optimise wall structure and window stress. The window can be replaced with a thicker glass of the same construction and lower cost to improve its overall thermal performance.

Author Contributions: Conceptualisation, L.S. and F.Z.; methodology, F.Z.; software, S.L. and Q.M.; validation, S.L.; formal analysis, F.Z.; investigation, F.Z. and Q.M.; resources, L.S. and S.L.; data curation, J.Z. and J.S.; writing—original draft preparation, F.Z.; writing-review and editing, Q.M.; visualisation, J.Z.; supervision, J.S. All authors have read and agreed to the published version of the manuscript.

Funding: This research was funded by the Ministry of Education of Humanities (grant number: 20YJCZH105), Natural Science Foundation of Hunan Province of China (grant number: 2020JJ4720), and the Key R\&D Projects of Hunan Province of China (grant number: 2019SK2183). 


\section{Institutional Review Board Statement: Not applicable.}

Informed Consent Statement: Informed consent was obtained from all subjects involved in the study.

Data Availability Statement: Data available on request due to restrictions of privacy. The data presented in this study are available on request from the corresponding author. The data are no publicly available due to privacy. Please contact corresponding author before use.

Acknowledgments: The authors would like to thank Z.M.Q. and L.Z. for excellent technical support, data curation, and investigation.

Conflicts of Interest: The authors declare that they have no known competing financial interests or personal relationships that could have appeared to influence the work reported in this paper.

\section{References}

1. Lippiatt, N.; Ling, T.-C.; Pan, S.-Y. Towards carbon-neutral construction materials: Carbonation of cement-based materials and the future perspective. J. Build. Eng. 2020, 28, 101062. [CrossRef]

2. Eberhardt, L.C.M.; Rønholt, J.; Birkved, M.; Birgisdottir, H. Circular Economy potential within the building stock-Mapping the embodied greenhouse gas emissions of four Danish examples. J. Build. Eng. 2021, 33, 101845. [CrossRef]

3. Wu, X.-H.; He, M.-L.; Cao, S.-C.; Shi, Y.-J. Evolution trend analysis of urban residents' low-carbon travel development based on multidimensional game theory. J. Cent. South Univ. 2019, 26, 3388-3396. [CrossRef]

4. Almusaed, A.; Almssad, A.; Homod, R.Z.; Yitmen, I. Environmental Profile on Building Material Passports for Hot Climates. Sustainability 2020, 12, 3720. [CrossRef]

5. Jannat, N.; Hussien, A.; Abdullah, B.; Cotgrave, A. Application of agro and non-agro waste materials for unfired earth blocks construction: A review. Constr. Build. Mater. 2020, 254, 119346. [CrossRef]

6. Mellaikhafi, A.; Tilioua, A.; Souli, H.; Garoum, M.; Hamdi, M.A.A. Characterization of different earthen construction materials in oasis of south-eastern Morocco (Errachidia Province). Case Stud. Constr. Mater. 2021, 14, e00496. [CrossRef]

7. Wang, J.; Huang, Y.; Teng, Y.; Yu, B.; Wang, J.; Zhang, H.; Duan, H. Can buildings sector achieve the carbon mitigation ambitious goal: Case study for a low-carbon demonstration city in China? Environ. Impact Assess. Rev. 2021, 90, 106633. [CrossRef]

8. Wu, Y.; Shen, L.; Shuai, C.; Jiao, L.; Liao, S.; Guo, Z. Key driving forces on the development of low carbon city (LCC) in China. Ecol. Indic. 2021, 124, 107379. [CrossRef]

9. Qi, Y.; Stern, N.; He, J.-K.; Lu, J.-Q.; Liu, T.-L.; King, D.; Wu, T. The policy-driven peak and reduction of China's carbon emissions. Adv. Clim. Chang. Res. 2020, 11, 65-71. [CrossRef]

10. Fang, K.; Tang, Y.; Zhang, Q.; Song, J.; Wen, Q.; Sun, H.; Ji, C.; Xu, A. Will China peak its energy-related carbon emissions by 2030? Lessons from 30 Chinese provinces. Appl. Energy 2019, 255, 113852. [CrossRef]

11. Zhang, T.; Hu, Q.; Ding, Q.; Zhou, D.; Gao, W.; Fukuda, H. Towards a Rural Revitalization Strategy for the Courtyard Layout of Vernacular Dwellings Based on Regional Adaptability and Outdoor Thermal Performance in the Gully Regions of the Loess Plateau, China. Sustainability 2021, 13, 13074. [CrossRef]

12. Xu, C.; Li, S.; Zhang, X.; Shao, S. Thermal comfort and thermal adaptive behaviours in traditional dwellings: A case study in Nanjing, China. Build. Environ. 2018, 142, 153-170. [CrossRef]

13. Hou, X.; Cheng, B.; Yang, J. A quantitative study on the exterior wall texture of stone-built dwellings in traditional villages in China: A case study of the Xisuo village in the Jiarong Tibetan area. J. Build. Eng. 2021, 42, 102357. [CrossRef]

14. Li, E.; Zhu, J. Parametric analysis of the mechanism of creating indoor thermal environment in traditional houses in Lhasa. Build. Environ. 2022, 207, 108510. [CrossRef]

15. Ozarisoy, B.; Altan, H. Systematic literature review of bioclimatic design elements: Theories, methodologies and cases in the South-eastern Mediterranean climate. Energy Build. 2021, 250, 111281-111307. [CrossRef]

16. Palme, M.; Guerra, J.; Alfaro, S. Thermal Performance of Traditional and New Concept Houses in the Ancient Village of San Pedro De Atacama and Surroundings. Sustainability 2014, 6, 3321-3337. [CrossRef]

17. Timur, B.A.; Başaran, T.; İpekoğlu, B. Thermal Retrofitting for Sustainable Use of Traditional Dwellings in Mediterranean Climate of Southwestern Anatolia. Energy Build. 2021, 256, 111712. [CrossRef]

18. Zhu, X.; Liu, J.; Yang, L.; Hu, R. Energy performance of a new Yaodong dwelling, in the Loess Plateau of China. Energy Build. 2014, 70, 159-166. [CrossRef]

19. Caro, R.; Sendra, J.J. Are the dwellings of historic Mediterranean cities cold in winter? A field assessment on their indoor environment and energy performance. Energy Build. 2021, 230, 110567. [CrossRef]

20. Wang, H.-F.; Chiou, S.-C. Spatial Form Analysis and Sustainable Development Research of Traditional Residential Buildings. Sustainability 2020, 12, 637. [CrossRef]

21. Gou, S.; Li, Z.; Zhao, Q.; Nik, V.M.; Scartezzini, J.-L. Climate responsive strategies of traditional dwellings located in an ancient village in hot summer and cold winter region of China. Build. Environ. 2015, 86, 151-165. [CrossRef]

22. Faria, L.; Romero, M.; Pirró, L. Evaluation of a Coupled Model to Predict the Impact of Adaptive Behaviour in the Thermal Sensation of Occupants of Naturally Ventilated Buildings in Warm-Humid Regions. Sustainability 2020, 13, 255. [CrossRef] 
23. Saljoughinejad, S.; Sharifabad, S.R. Classification of climatic strategies, used in Iranian vernacular residences based on spatial constituent elements. Build. Environ. 2015, 92, 475-493. [CrossRef]

24. Juan, X.; Ziliang, L.; Weijun, G.; Mengsheng, Y.; Menglong, S. The comparative study on the climate adaptability based on indoor physical environment of traditional dwelling in Qinba mountainous areas, China. Energy Build. 2019, 197, 140-155. [CrossRef]

25. Zeng, Z.; Li, L.; Pang, Y. Analysis on climate adaptability of traditional villages in Lingnan, China-World Cultural Heritage Site of Majianglong Villages as example. Procedia Eng. 2017, 205, 2011-2018. [CrossRef]

26. Min, T.; Zhang, T. Study on the Climate Adaptability of Architectural Interface Opening in Suzhou's Regional Residences. Procedia Eng. 2016, 169, 108-116. [CrossRef]

27. Zhu, J.; Nie, P.; Li, R.; Tong, L.; Zhao, X. Climate Responsive Characteristics of Cliff-side Cave Dwellings in Cold Area of China. Energy Procedia 2019, 158, 2731-2736. [CrossRef]

28. Khodabakhshian, M. Comparative Study on Cliff Dwelling Earth-shelter Architecture in Iran. Procedia Eng. 2016, 165, 649-657. [CrossRef]

29. Kaihoul, A.; Sriti, L.; Amraoui, K.; Di Turi, S.; Ruggiero, F. The effect of climate-responsive design on thermal and energy performance: A simulation based study in the hot-dry Algerian South region. J. Build. Eng. 2021, 43, 103023. [CrossRef]

30. Mohammadi, A.; Saghafi, M.R.; Tahbaz, M.; Nasrollahi, F. The study of climate-responsive solutions in traditional dwellings of Bushehr City in Southern Iran. J. Build. Eng. 2018, 16, 169-183. [CrossRef]

31. Smith, W.D. Hippocrates. Encyclopedia Britannica. Available online: https://www.britannica.com/biography/Hippocrates (accessed on 18 May 2020).

32. Olgyay, V. Bioclimatic Evaluation Method for Architectural Application. In Biometeorology; Tromp, S.W., Ed.; Pergamon: Oxford, UK, 1962; pp. 246-261.

33. Maxineasa, S.G.; Isopescu, D.N.; Baciu, I.-R.; Lupu, M.L. Environmental Performances of a Cubic Modular Steel Structure: A Solution for a Sustainable Development in the Construction Sector. Sustainability 2021, 13, 12062. [CrossRef]

34. Liang, L.; Wen, B.; Xu, F.; Yan, J.; Yan, X.; Ramesh, S. Linking the Development of Building Sustainability Assessment Tools with the Concept Evolution of Sustainable Buildings. Sustainability 2021, 13, 12909. [CrossRef]

35. Mileto, C.; Vegas, F.; Llatas, C.; Soust-Verdaguer, B. A Sustainable Approach for the Refurbishment Process of Vernacular Heritage: The Sesga House Case Study (Valencia, Spain). Sustainability 2021, 13, 9800. [CrossRef]

36. Kumar, S.; Singh, M.K.; Kukreja, R.; Chaurasiya, S.K.; Gupta, V.K. Comparative study of thermal comfort and adaptive actions for modern and traditional multi-storey naturally ventilated hostel buildings during monsoon season in India. J. Build. Eng. 2019, 23, 90-106. [CrossRef]

37. Manu, S.; Brager, G.; Rawal, R.; Geronazzo, A.; Kumar, D. Performance evaluation of climate responsive buildings in India-Case studies from cooling dominated climate zones. Build. Environ. 2019, 148, 136-156. [CrossRef]

38. Zhu, J.; Xing, C.; Li, R.; Li, C.; Zhao, X. Experimental and theoretical investigation of thermal performance of Yaokang heating system in China. Energy Build. 2020, 226, 110344. [CrossRef]

39. Zhu, J.; Tong, L.; Li, R.; Yang, J.; Li, H. Annual thermal performance analysis of underground cave dwellings based on climate responsive design. Renew. Energy 2020, 145, 1633-1646. [CrossRef]

40. Jin, Y.; Zhang, N. Comprehensive Assessment of Thermal Comfort and Indoor Environment of Traditional Historic Stilt House, a Case of Dong Minority Dwelling, China. Sustainability 2021, 13, 9966. [CrossRef] 